than growing - making us seem more and more like ants. In such times, we need hopeful books like this and more heroes such as Raff or Wilson.

Robert Dunn is an ecologist in the Department of Biology at North Carolina State University, Raleigh, North Carolina 27695, USA. He is the author of Every Living Thing: Man's Obsessive Quest to Catalog Life, from Nanobacteria to New Monkeys. e-mail:rob_dunn@ncsu.edu

\title{
Under the skin of climate change
}

\section{Solar \\ by lan McEwan \\ Jonathan Cape: 2010. 304 pp. \\ $\$ 26.95, £ 18.99$}

Following his 2005 novel Saturday, in which the central character is a neurosurgeon, in his latest book celebrated British author Ian McEwan explores the personal side of the science and politics of climate change. A sophisticated work of fiction, Solar is littered with references to physics and engineering. Its intention, however, is to show scientists as social actors beyond the idealized stereotype.

McEwan's narrative follows British theoretical physicist Michael Beard from 2000 to 2009 , a decade when the world is adjusting to the perspective of anthropogenic climate change. Beard has already been anointed with the "magic dust" from Stockholm - the Nobel prize. His productive research is behind him; he has turned instead to chasing women and converting his magic dust into money by taking up advisory jobs. Beard is a good observer, an intelligent and clever man.

The story focuses not on global warming itself but on how Beard turns the opportunities that arise to his own ends. As a consequence, he changes. He starts out "not wholly sceptical", unimpressed by suggestions "that humankind was drifting towards calamity". He opines that "the end of the world was never pitched in the present, where it could be seen for the fantasy it was". Later, he adopts a different position: "The planet is sick. Curing the patient is a matter of urgency and is going to be expensive". The question of the book is how this transformation takes place.

The answer is through both need and opportunity. Beard's attentions are redirected after he meets the young, idealistic postdoc Tom Aldous, who pushes the idea of using photosynthesis on an industrial scale to produce clean energy. Aldous pleads with Beard to read his proposals - without success. But after Aldous meets his fate on a polar-bear rug,

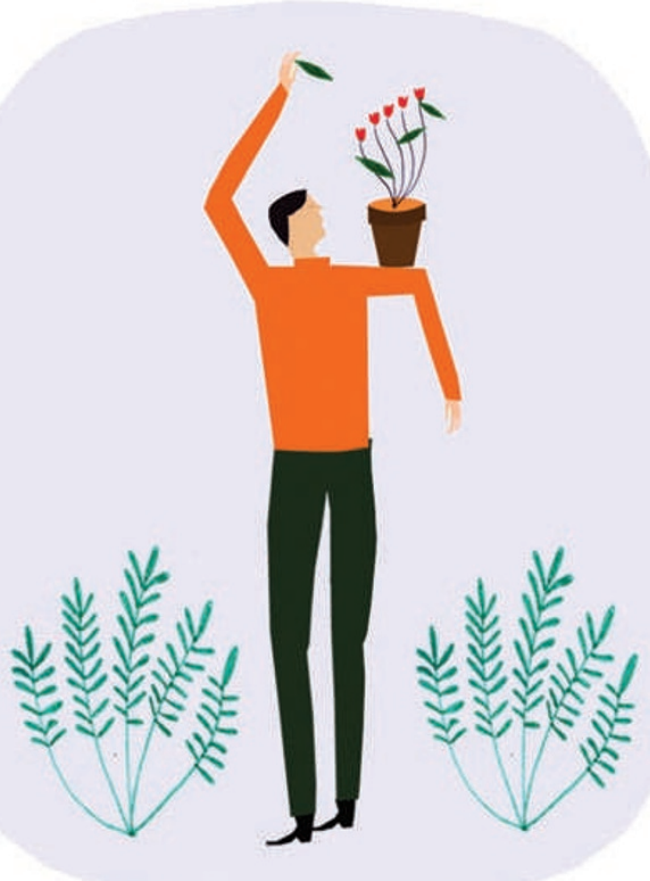

Beard does eventually look into the postdoc's files. In them he spots a blueprint for making money - lots of money - and for gaining an even greater reputation.

Beard establishes a consortium and, after the remaining scientific and technical problems are solved, builds a small demonstration plant in New Mexico. He persuades his investors of the urgency of producing clean energy but assures them that they will "get rich along the way". He encourages sceptical co-workers with remarks such as: "Here's the good news. The UN estimates that already a third of a million people a year are dying from climate change." Or, equally cynically: "It's a catastrophe. Relax!" But in the end, Beard's quest doesn't solve his problems - legal, medical or personal.

Although the plot is simplistic and the ending unconvincing, Solar is an interesting character study. McEwan's description of a fictional scientist who has received the ultimate award but who suffers from that very recognition is apt; Beard pays his 'Nobel price' by no longer being allowed to work as an ordinary scientist. He is smart enough to know that he cannot save the world, but he is also clever and unscrupulous enough to take a chance and jump on the climate-change bandwagon.

Solar is not a wake-up call for the public to take climate change seriously; nor does it serve sceptics who consider climate change a hoax. It is not a static stage on which wooden characters declare some preconceived truth, as in the sciencefiction film The Day after Tomorrow (2004) and the Michael Crichton thriller, State of Fear (HarperCollins, 2004). Instead, it is a book about climate change as a social construct in the real world. It is especially appropriate at a time when the motivations of climate scientists are under scrutiny.

Hans von Storch is a director at the Institute of Coastal Research of the GKSS Research

Centre, D-21502 Geesthacht, Germany, and a member of the KlimaCampus of the University of Hamburg, D-20146 Hamburg, Germany. e-mail:hvonstorch@web.de

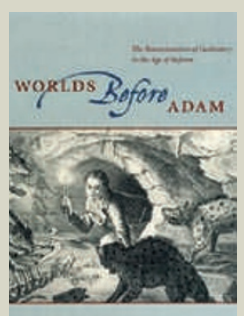

namisnows
Worlds Before Adam: The Reconstruction of Geohistory in the Age of Reform

by Martin J. S. Rudwick (Chicago Univ. Press, E22.50)

This history of Earth science reveals that the emergence of modern geology was "comparable in its cultural impact with that of relativity or Darwinian evolution", wrote reviewer Victor Baker. "Rudwick highlights an underappreciated, glorious advance in human thought, the documentation of which is a rather glorious achievement in itself." (Nature 454, 406-407; 2008.)

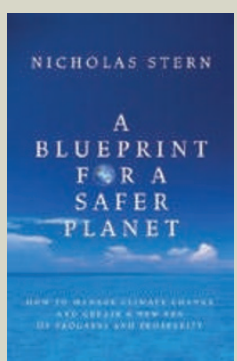

A Blueprint for a Safer Planet: How We Can Save the World and Create Prosperity by Nicholas Stern (Vintage, $£ 8.99$ ) Economist Nicholas Stern lays out a road map for managing the climate crisis, describing the dangers of climate change and examining possible responses. "Stern presents an up-to-date, logically argued synthesis, using a style that makes his book more intelligible than many others on the topic." (Robert Costanza, Nature 458, 1107-1108; 2009.) 